The Journal of Public Space

ISSN 2206-9658

2018 | Vol. 3 n. 2

https://www.journalpublicspace.org

\title{
A situated practice
}

Fiona Hillary

RMIT University, Australia

fiona.hillary@rmit.edu.au

\begin{abstract}
A situated practice explores one artist's approach to navigating the shifts and changes inherent in the public space of the post-industrial city and suburbs of Melbourne, Australia. Collaborative, ephemeral, site-specific, relational works in three specific sites; Station Pier in Port Melbourne, automated pedestrian crossings throughout the city, and at the Western Treatment Plant, the sewerage facility on the western edge of Melbourne's urban sprawl, explore everyday public sites to stake a claim for the imagination. Engaging with the work of critical theorists including Rosi Braidotti, Franco Bifo Berardi and Donna Haraway I am interested in how the abstraction of ordinary experiences and spaces allow artists and audience to co-constitute the possibility of something other, triggering fleeting transformative acts of imagination. Through this body of work, I am learning how to leave the marks of care for the future and 'stay with the trouble.' (Haraway, 2016, p.10).
\end{abstract}

Keywords: situated practice, public art, post-humanism, refrain, rhythm, resonance, everyday, borders, urban future

\section{To cite this article:}

Briggs, R. (2018). Using drawing as a tool to explore public space. The Journal of Public Space, 3(2), I49-166, DOI 10.3289|/jps.v3i2. III3

This article has been accepted for publication in The Journal of Public Space. Please see the Editorial Policies under the 'About' section of the journal website for further information.

This work is licensed under a Creative Commons Attribution - Non Commercial 4.0 International License https://creativecommons.org/licenses/by-nc/4.0/ 
Whatever increases your capacity to act and intervene in the world - intervene in the public sphere - for the love of the world.

(Braidotti, 20I4)

In a field of posthuman enquiry and experimentation, Rosi Braidotti, implores us to act, to question, to generate new collaborative ways of being in the world, generating work through situated practice; locating work in our own reality and experience. (Braidotti \& Hlavajova, 2017, p. I) Public practice is a discursive category of creative work that employs a broad lexicon of ideas, modes and materials to make culture in civic spaces. This evolving practice takes multiple forms and has long been recognized for its capacity to reflect, intervene, disrupt and ameliorate on and in place/space or relational forms of place/space. My interest in public practice is located between visual, performative and social practices. It lies in the capacity for creative public practice to explore how we vision the future and asks what can public practice do to intervene in our rehearsal of the future?

I am interested in Franco Bifo Berardi's ideas of rhythm, movement and refrain in his recent publication END: Phenomenology of the end he says:

The way a society, culture, or a person perceives time is also a model of truly temporal refrain, that is of particular rhythmic modulations that act as ways to access cosmic temporal becomings and attune to them.

The stuff that composes a refrain is essentially rhythm. Singular refrains can create a common space of resonance, and a new form emerges as a new rhythm. It is the new rhythm that makes it possible to see a new landscape.

(Berardi, 2015, p. 317)

Here I offer a journey through three temporal site-specific public works - Are You Here; Crossings; and $37^{\circ} 57^{\prime} 02.5^{\prime \prime} \mathrm{S} 144^{\circ} 38^{\prime} 02.0^{\prime \prime} \mathrm{E}$. Each work draws on the movements and rhythms of the space and creates a resonance in the everyday functioning of sites in an attempt to intervene in public space with the hope of visioning new landscapes.

Are You Here was a public/socially engaged work, co-created across the summer of 2015/16 with collaborator Benjamin Cittadini. For eight weeks in four shipping containers at Station Pier, we established a processing centre, processing people's journey from the present to the future. Station Pier is Melbourne's second biggest border entry port to Victoria, Australia after the Melbourne Airport. According to Victorian Ports Melbourne. 'operating for over 150 years, the pier has been important in almost every phase of Australia's history.

- In war and peace.

- Commemoration and celebration.

- Servicemen returning home.

- Migrants arriving from distant lands.

- Refugees arriving from war zones.' (Victorian Ports Melbourne, 2005)

The contemporary Station Pier ushers people from their cruise ships as a point of destination or as a tourist in transition from P \& O ships. At Station Pier the Spirit of Tasmania disembarks twice a day for Tasmania. The resident population of Port Melbourne has shifted significantly across time; originally home to the Boonwurrung people of the Kulin Nation, to a working class cohort servicing the port post colonization, to the present population of retirees and young professionals.

Are You Here 2016 consists of a suite of soundscapes, developed by my collaborator Benjamin Cittadini, that welcomed and farewelled the travellers, in part a reference to Brian Eno's ambient works for non-spaces (Eno, 1978). Within this soundscape we invited people to 
document their visit with a polaroid photo, taken in front of a 1970's styled vision of a future city, as a souvenir to take into the future. We created performative interventions, establishing a ritual farewell for the cruise ships from the present into the future. An immersive projection work, of the ocean the ships sailed on or the sky they sailed beneath, created a platform for spontaneous participatory performance. A neon sign flashed incoherently, you here are, here you are, are you here; gold tents constructed from foil safety blankets offered shelter from the wind and a video work documented the rituals of arrival and departure. A traffic management official working on loading cars on to the Spirit of Tasmania signaled to me to approach him. It seemed he had something he wanted to say-apprehensively expecting him to reveal we were in breach of some port legislation I approached - instead, as sweat dripped from his heat affected face, he thanked me for the soundscapes, they changed his normally intense day and he felt like they changed the mood of the people in the cars that lined up for a kilometer along the esplanade in the summer heat. Each day passers-by would ask what we were doing there, each day new ideas about our purpose were generated - for example the shipping containers and a near-by demolition site ignited people's interest in the potential of a re-development on the site, giving us the opportunity to engage in conversations about what that might look like. In the evenings, the projections created a performative framing for people who playfully explored their own presence in the glow of the projected works. As one family walked away with their souvenir family portrait, I heard the adult male say to his family - 'this means we'll be together in the future'.

Cittadini and I tended the works every day in non-descript uniforms - as non-descript kind of workers. Through this work we intervened in the rhythmic modulations of the site creating a form of social rupture that generated a temporary new resonance in the everyday function of Station Pier.

Are You Here extended a range of process-based and participatory public sphere strategies previously examined in Crossings (2015), a collaboration with Benjamin Cittadini, Ceri Hann and Shanti Sumartojo. Crossings explored more personally located borders within the legislated landscape of the city. A repetitive, ritualised action by four associates; three artists and a cultural geographer, again in non-descript uniforms, collectively occupied a series of automated pedestrian crossings throughout the city of Melbourne and its surrounding suburbs. A generative/iterative series of actions worked by both locating ourselves in, and interrogating, the physical site; experiencing social and legislative borders that created dialogue between us as practitioners and with the everyday users of the pedestrian crossings we interrogated. The rhythm of the street chimed into order as the 'Audio Tactile Pedestrian Detectors' sounded their commanding tones and set a pace, our presence played with this order and the expectations of the people entering to perform their daily journeys through the city.

In one iteration, we were joined by other people mimicking our repeated actions. I stood still waiting for the lights to change, a man looked me up and down, as the lights changed I noticed him looking at his own attire, it was as if he was checking to see how we fitted together, if in fact we did. To some we were invisible, there was a sense the unseeing pedestrian would work hard not to see us. One woman couldn't work out how to navigate her pathway around me with her suitcase of belongings, she expressed her exasperation as if $\mathrm{I}$, in my non-descript uniform had no right to be there - the nondescript uniform seemed to offer a sense of authority for people to rub up against. There were personal borders being pulled close and tight as pedestrians performed to the beat of the legislative borders of the automated pedestrian crossing.

'Are you Here' and 'Crossings' are examples of site specific works grounded in the reality of their location: geographical, psychological, political and philosophical borders as they intersect with individual and collective movement. We created temporary incursions into everyday 
contexts impacting the social imaginaries at play in each location. Representation is critical to Braidotti's thinking in the 'First Supper Symposium' she asks if 'we are often represented as the 'subjects of catastrophe' what can the imagination do to cut through or challenge this representation?' (Braidotti, 2014) While Braidotti is skeptical of dystopian frameworks she is clear that 'the imagination is not utopian, but rather transformative and inspirational. Hope is a vote of confidence in the future...'(Braidotti, 20I I, p. 14) She appeals to her audience to work toward 'horizons of hope' to navigate the future.

Simon Sheikh quotes Walter Benjamin in The Arcades Project when he postulates, "the present...already stands to the recent past as the awakening stands to the dream...Every epoch, in fact, not only dreams the one to follow but in this dreaming, precipitates its awakening" (Sheikh, 20 I , p. 165). I am interested in the potential limitations of framing the imagination and framing the future. Like Braidotti, Sheikh calls us to invoke our radical imagination 'which is where art has a crucial role to play in providing vectors of the possible, posing questions of possibility and vicinity, as well as making invisible limits visible within the ontology of the horizon' (Sheikh, 20II, p. 164).

The public work $37^{\circ} 57^{\prime} 02.5^{\prime \prime} \mathrm{S} 144^{\circ} 38^{\prime} 02.0^{\prime \prime} \mathrm{E} 2017$ was located in the vast horizon of the Western Treatment Plant (WTP), where people have for generations shifted between the present and the future. A durational ensemble performance for the future was proposed as an act of recuperation. In the tradition of Edward Said and Daniel Barenboim's orchestra West-Eastern Divan (1999) the work is intended to trigger dialogue, between artists, audience and site.

$37^{\circ} 57^{\prime} 02.5^{\prime \prime} \mathrm{S} 144^{\circ} 38^{\prime} 02.0^{\prime \prime} \mathrm{E}$ (2017) was part of Treatment: Flightlines curated by Cameron Bishop and David Cross as an investigative creative project to creatively explore the Western Treatment Plant (WTP) in Melbourne's western districts, thirty-nine kilometers from Melbourne's Central Business District. Utilising the WTP as a test site of practice began as a journey to explore a rapidly transitioning landscape on the edge of Melbourne's urban sprawl as post-industrial sites are being remunerated and transformed into the contemporary urban Australian dream, a house on a quarter acre block. Werribee is renown historically and in the present as a test site in many ways.

The work of the Western Treatment Plant, through experimentation and research has seen incredible contributions to advanced cutting-edge human waste treatment processes critical in sustaining our rapidly expanding urban populations, Melbourne Water treats over 320,000,000 litres of sewerage each year through the Eastern and Western Treatment Plant (Water, 2018b) The development of Anaerobic lagoons at WTP, covered in plastic tarps has not only reduced greenhouse gas emissions and the aroma of the lagoons by capturing the gases, but provides gas that is able to power engines that generate electricity (Water, 2018c). Within the Western treatment plant lies the small abandoned township of Cocoroc. Cocoroc was built in 1894 to house the workers of the Metropolitan Sewerage Farm. The township grew across time - houses, a community swimming pool, a town hall and football ground, tennis courts, schools and a post office. By the 1970s Cocoroc was home to a population of 500. In the 70s it was too expensive for the Melbourne and Metropolitan Board of works to maintain and residents were effectively relocated into the suburb of Werribee. (Water, 2018a) What remains of the township now, and is imminently about to change is the Water Tower, the swimming pools, a football oval and change rooms and a community hall. The Water Tower at Cocoroc was built in another century, originally in East Melbourne to deal with the rapid expansion of the city, Melbourne, providing clean water during cholera and typhoid outbreaks. It was moved and rebuilt in Cocoroc in 1892 - the official record says it provided a back-up water supply to Cocoroc until 1924, but word on the ground is that it was never really used for this purpose - there is something interesting in its form as an empty icon. 
There is something potent in the generative progressive nature of durational performance on site, creating and exploring the intervals, interstices between the post-industrial landscape looking toward a posthuman landscape. I am interested in assemblages that explore alternative narratives/stories of site that breathe with the space. There is something ceremonial - in the singular and collective act.

A call out via social media invited respondents to submit a song that reminded them of the future, or that they would take into the future. Eighty nine songs later, with one original composition from one of the staff of the WTP, I extended an invitation to four electric guitarists; Billy Miller, Penny Ikinger, Sorcha Wilcox and Benjamin Cittadini to respond to the set list. Each guitarist chose four songs and through the seven hour performances they became abstracted, they became something else - a collaborative statement about the present, the time spent in the water tower, the resonance of the past and present reaching out across the landscape enveloping all that lay in its wake. The work claimed the space in concert with the occupants of the site for those two seven hour performances.

I am interested in the multiplicity of readings of our times - triggering ruptures in affect to generate some kind of resonance in an attempt to create spaces or moments for 'recuperation'. (Haraway, 2016) Creating a space - a moment - where affect shifts constituting an encounter with sound, light and the resonance of the space. Sometimes the sound is too loud, too abstract, sometimes there is a familiarity in the sound - a soothing call providing a moment to consider how we 'stay with the trouble' when listening to the lone strains of the guitar through a seven hour performance. (Haraway, 2016)

As the community of Cocoroc was being moved to Werribee, rock and roll was taking centre stage in Australian culture - Countdown, a popular weekly Australian music television show, never came to Cocoroc as there were no TVs. This work marked that missing period in time. This was a durational sound performance for the future - a moment in time that created encounter while tearing an affective schism in time and the landscape.

Affect is born in in-between-ness and resides as accumulative beside-ness.

(Seigworth and Gregg, 2010, p.3)

Drawing on Louis Helbig's aerial photography of the site, neon configurations were constructed from recycled lengths of neon, reflecting the purpose of WTP in recycling our waste. Electric guitars and neon are both reliant on vibration and reverberation, as the hours passed and a smokey haze filled the space, like the sound outside the neon floated in the void. The empty water tank amplified abstracted strains of PJ Harvey's We Float, the Knightrider Theme, Gary Newman's Cars and Helen Reddy's I am woman. The landscape was enveloped in sound, an hourly refrain that repeatedly filled the spaces in between, the spaces of becoming, a call and response almost between a human yearning and other non-human occupants of the site.

The refrain of the electric guitars could be felt through my feet, vibrating through the core of my physical being. The coloured glow of the neon reflected in the faces of the audience. 'It's like a dreamscape' one man shared with me, yelling into my ear to be heard above the guitarist. The strains of the music amplified across the site, one woman later told me she didn't realise she could enter the water tower - she thought the enveloping sound that resonated across the site was the artwork. As the abstracted strains of Somewhere Over the Rainbow rung out a woman approached me, tears brimming in her eyes, she said 'thankyou' and left the work.

Through my practice I am not tracing the world. Rather I am exploring the traces of the world through repetition and refrain that allow us to stay in the moment or usher us into the future. Inspired by Haraway to engage in acts of worlding (Haraway, 2016), as the urban 
landscape morphs around us - urbanization spreading and encroaching - reterritorializing public space, I stake a claim for the imagination - situated in the present, drawing on the past and creatively resonating us into the future.

\section{References}

Barenboim, D. \& Said, E. (1999) West-Eastern Divan Orchestra, Spain.

Braidotti, R. (20II). Nomadic subjects : embodiment and sexual difference in contemporary feminist theory: New York : Columbia University Press, c201 I. 2nd ed.

Braidotti, R. (2014). The First Supper Symposium. Paper presented at the The First Supper Symposium.

Braidotti, R. \& Hlavajova, M. (2018). Posthuman Glossary: London: Bloomsbury Academic.

Berardi, F. B. (20I5). AND: Phenomenology of the End. South Pasadena CA: Semiotext(e).

Cornell, D. S., Stephen D. (2017). What Has Happened to the Public Imagination, and Why? 2 Ist Century Global Dynamics, 10(19).

Eno, B. (1978) Ambient I: Music for Airports, Polydor Records.

Seigworth, G. J. \& Gregg, M. (20I0). The Affect theory reader: Durham, NC : Duke University

Press.

Haraway, D. J. (2016). Staying with the trouble : making kin in the chthulucene. Durham: Duke University Press, 2016. ISBN: 978- 0-8223-6224-I.

Mendieta, E. (2010). Postcolonialism, postorientalism, postoccidentalism: the past that never went away and the future that never arrived. In T. S. May, A.D. (Ed.), Emerging Trends in Continental Philosophy (Pp. 149 - 172): Acumen.

Sheikh, S. (20I I). Vectors of the Possible: Art between spaces of experience and horizons of expectations. In S. S. J. W. Maria Hlavajova (Ed.), On Horizons: A Critical Reader in Contemporary Art (pp. 162-166). Utrecht: BAK.

Victorian Ports Melbourne. 2005. Station Pier History. [Online] Available at: http://www.vicports.vic.gov.au/about-us/port-history/Pages/station-pier-history.aspx [Accessed 10 July 20I8]

Water, M. (2018c). Western Treatment Plant. Retrieved from https://www.melbournewater.com.au/community-and-education/about-ourwater/sewerage/western-treatment-plant

Fiona Hillary is a lecturer and Industry Fellow in the Master of Arts - Art in Public Space at the School of Art, RMIT University, Australia. Fiona curates the Urban Laboratory for RMIT University's Contemporary Art and Social Transformation CAST research group. The Urban Laboratory uses live test sites of practice to explore urban contexts engaging art practices in a research and project delivery model in partnership with local government. She is a practicing public artist, collaborating on a range of temporary and permanent investigative projects. Her most recent work $37^{\circ} 57^{\prime} 02.5^{\prime \prime S}$ $144^{\circ} 38^{\prime} 02.0^{\prime \prime} E$ marks the beginning of a creative cartography for the future. Fiona's research interests are in collaborative practice, the use of socially-engaged art practice as research methodology in public spaces with a specific focus on temporary installations. Fiona is a PhD Candidate at Deakin University exploring the role of public practice in reimaging futures. With Shanti Sumartojo she co-authored the paper Empty-Nursery Blue: On atmosphere, meaning and methodology in Melbourne street art published in Public Art Dialogue (20I4: 4: 2 :20I-220). 


\section{Are You Here}

2015-16

Are You Here was a public/socially engaged work, co-created with collaborator Benjamin Cittadini. For eight weeks in four shipping containers at Station Pier, we established a processing centre, processing people's journey from the present to the future.

Station Pier is Melbourne's second biggest border entry port to Victoria, Australia after the Melbourne Airport.

Are You Here 2016 consists of a suite of soundscapes, developed by my collaborator Benjamin Cittadini, that welcomed and farewelled the travellers, in part a reference to Brian Eno's ambient works for non-spaces. Within this soundscape we invited people to document their visit with a polaroid photo, taken in front of a 1970's styled vision of a future city, as a souvenir to take into the future. We created performative interventions, establishing a ritual farewell for the cruise ships from the present into the future.

An immersive projection work, of the ocean the ships sailed on or the sky they sailed beneath, created a platform for spontaneous participatory performance. A neon sign flashed incoherently, you here are, here you are, are you here; gold tents constructed from foil safety blankets offered shelter from the wind and a video work documented the rituals of arrival and departure.

\section{Are Youthere}



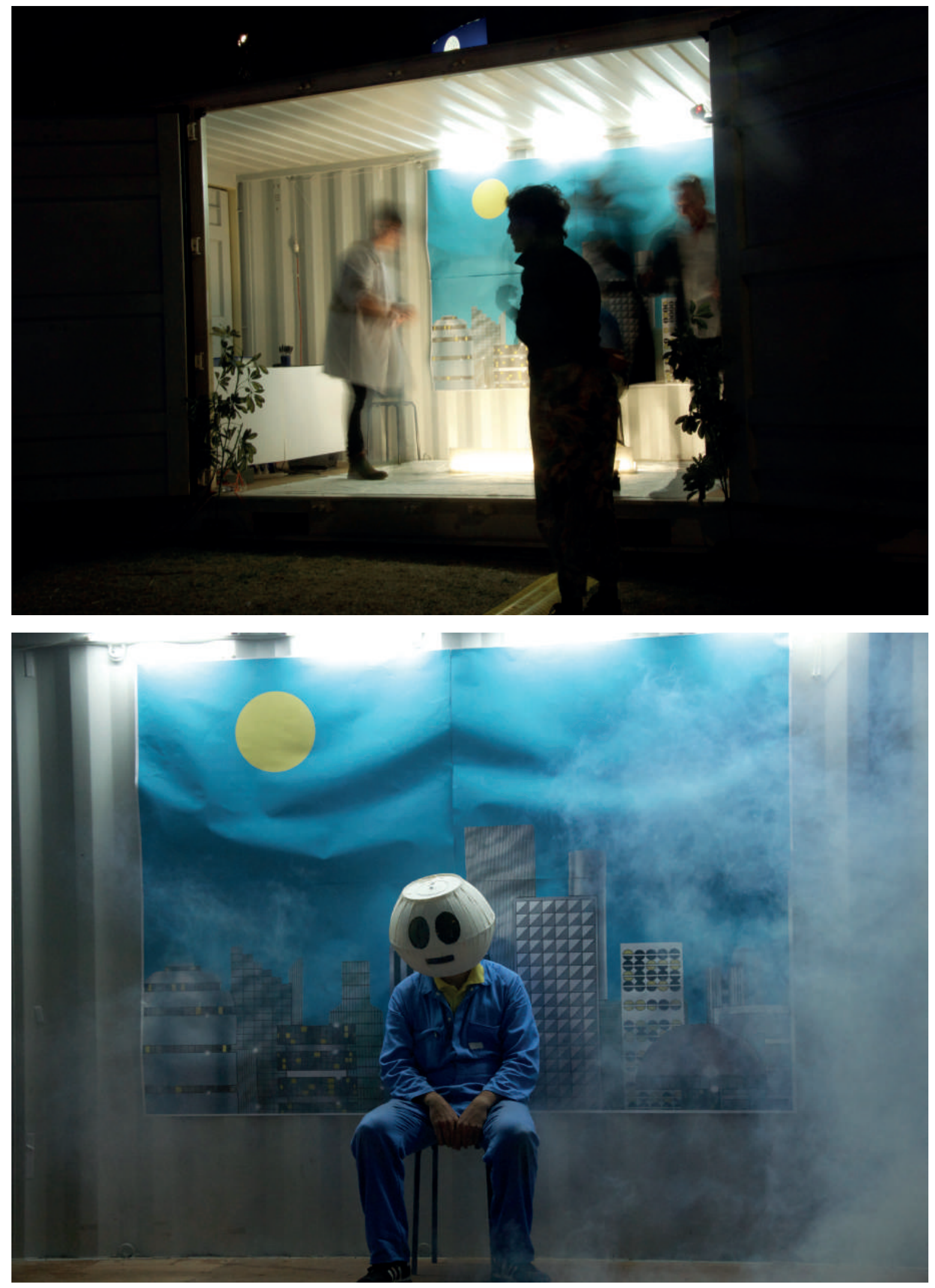

I56 | The Journal of Public Space, 3 (2), 2018 | ISSN 2206-9658

City Space Architecture / UN-Habitat 

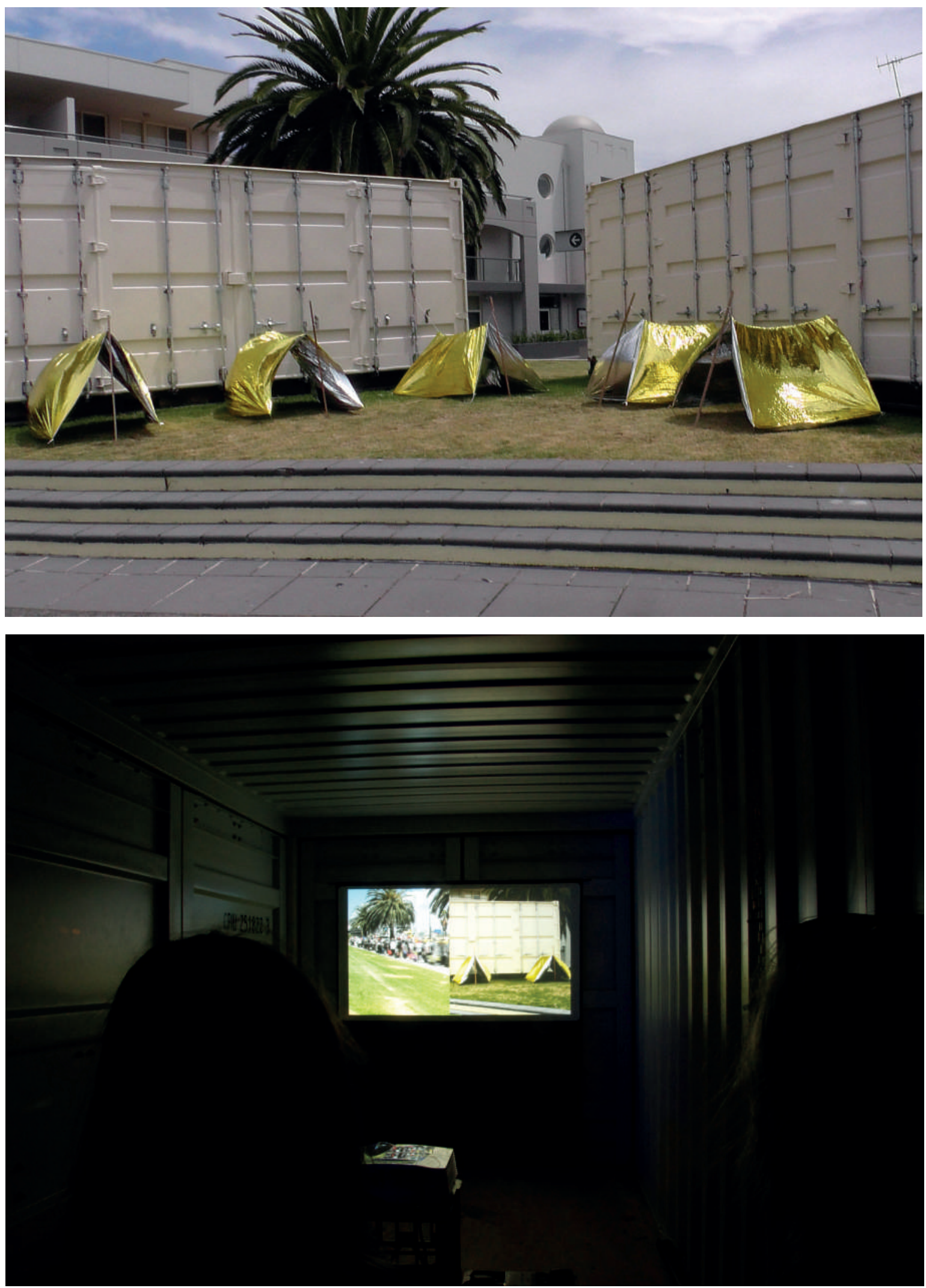

I57 | The Journal of Public Space, 3 (2), 2018 | ISSN 2206-9658 City Space Architecture / UN-Habitat 
Using drawing as a tool to explore public space

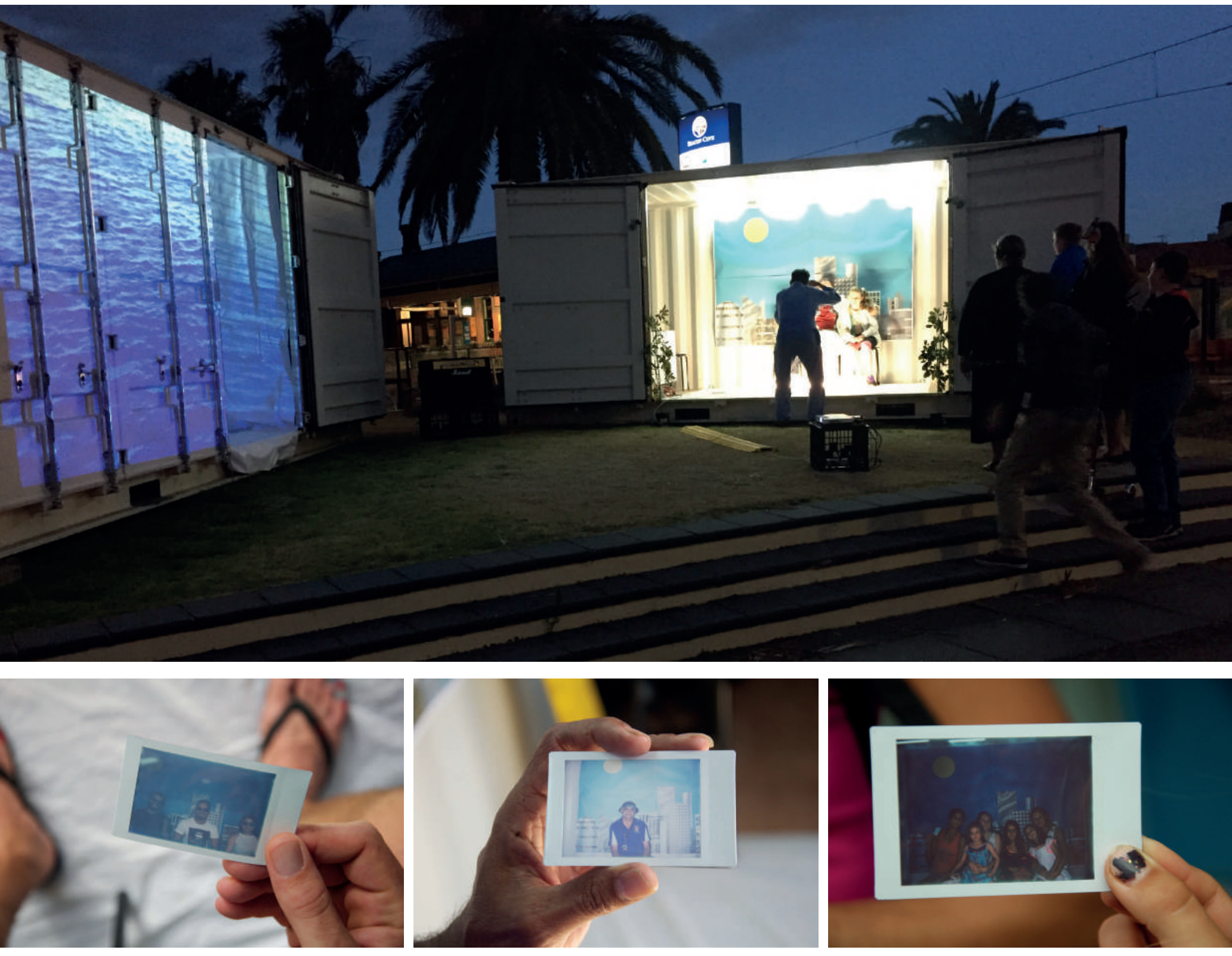

I58 | The Journal of Public Space, 3 (2), 2018 | ISSN 2206-9658

City Space Architecture / UN-Habitat 


\section{Crossings}

2015

Crossings was a collaboration with Benjamin Cittadini, Ceri Hann and Shanti Sumartojo. It explored more personally located borders within the legislated landscape of the city. A repetitive, ritualised action by four associates; three artists and a cultural geographer, again in non-descript uniforms, collectively occupied a series of automated pedestrian crossings throughout the city of Melbourne and its surrounding suburbs.

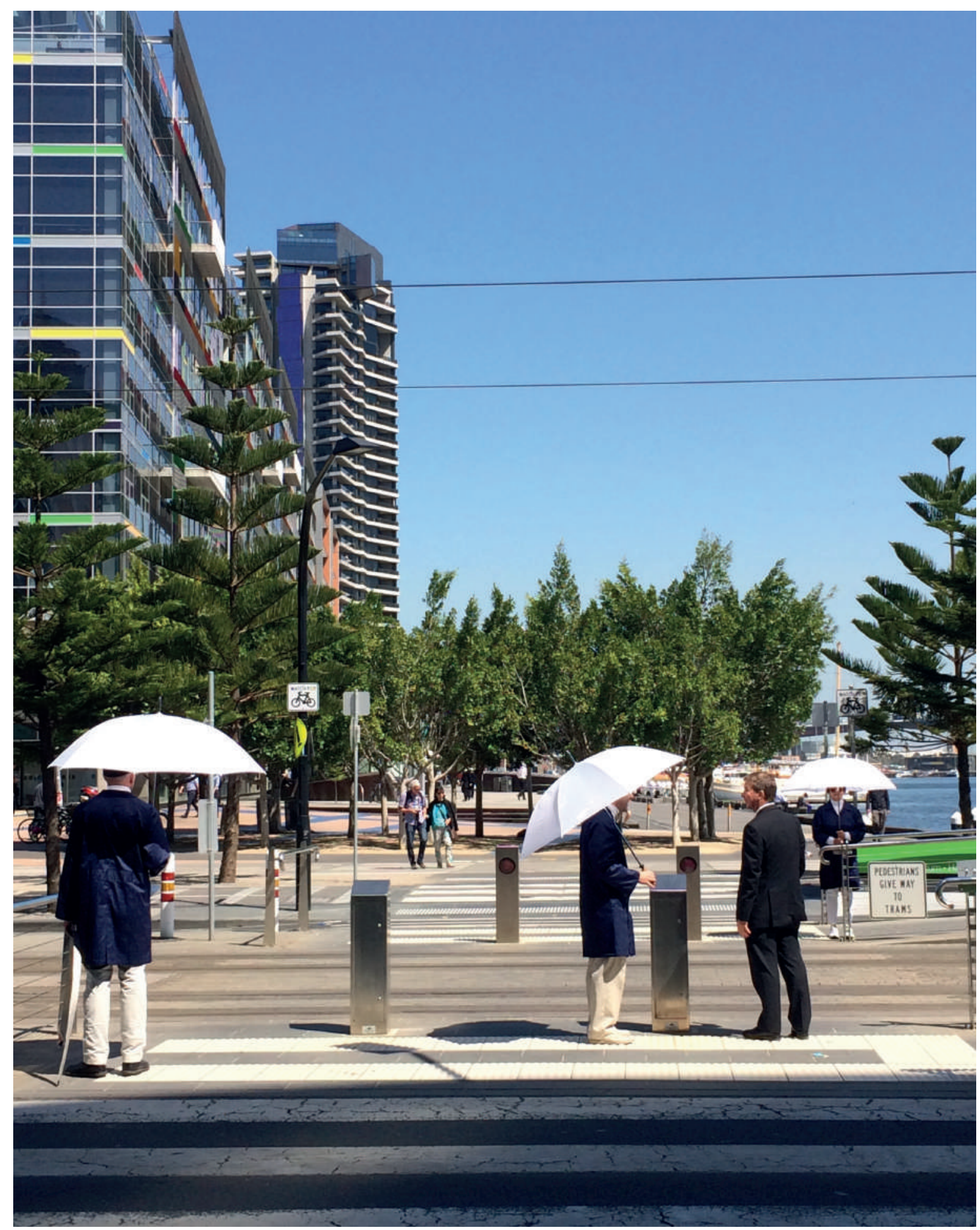

I59| The Journal of Public Space, 3 (2), 2018 | ISSN 2206-9658 City Space Architecture / UN-Habitat 
A generative/iterative series of actions worked by both locating ourselves in, and interrogating, the physical site; experiencing social and legislative borders that created dialogue between us as practitioners and with the everyday users of the pedestrian crossings we interrogated. The rhythm of the street chimed into order as the 'Audio Tactile Pedestrian Detectors' sounded their commanding tones and set a pace, our presence played with this order and the expectations of the people entering to perform their daily journeys through the city.
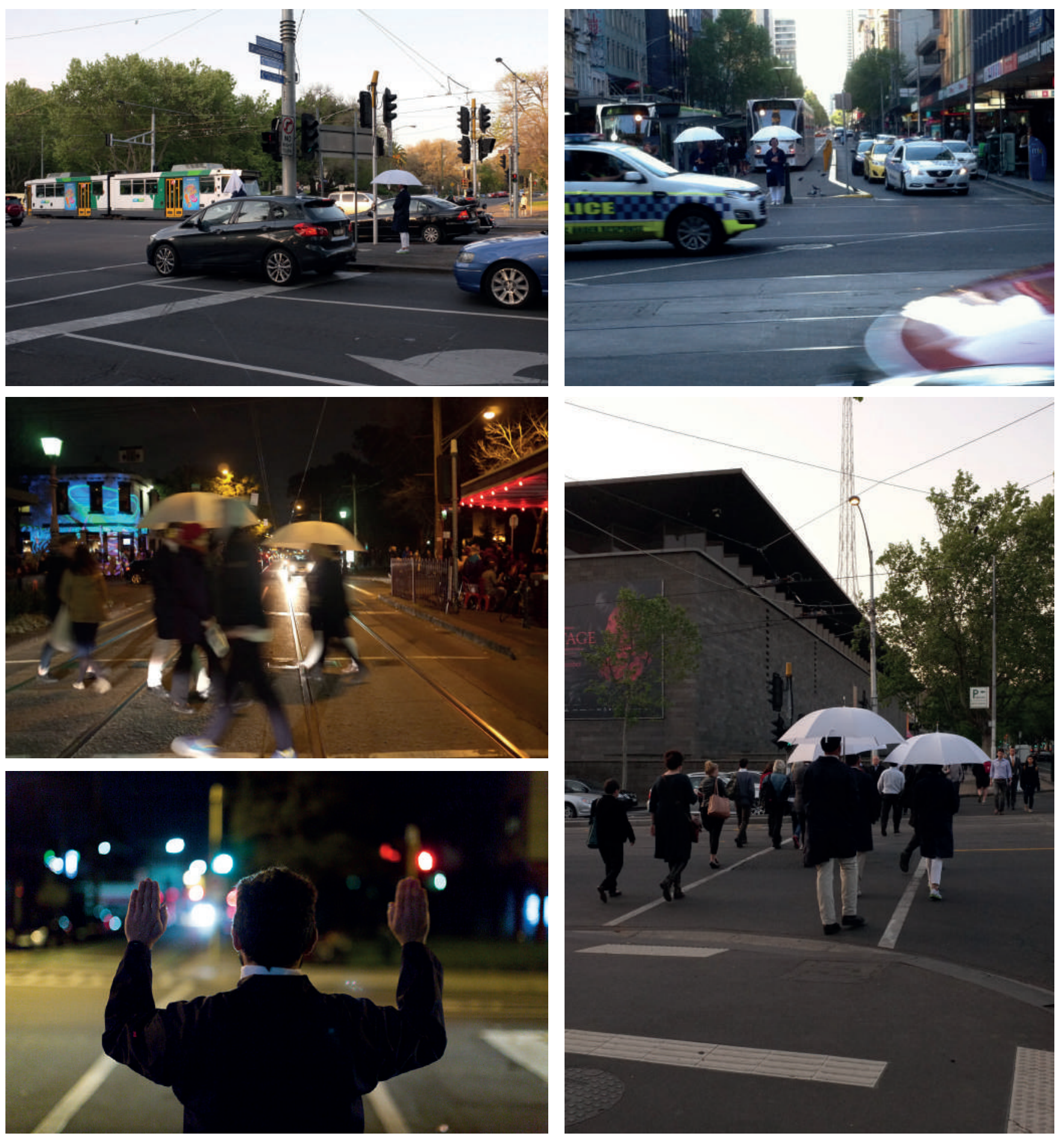

160 | The Journal of Public Space, 3 (2), 2018 | ISSN 2206-9658

City Space Architecture / UN-Habitat 

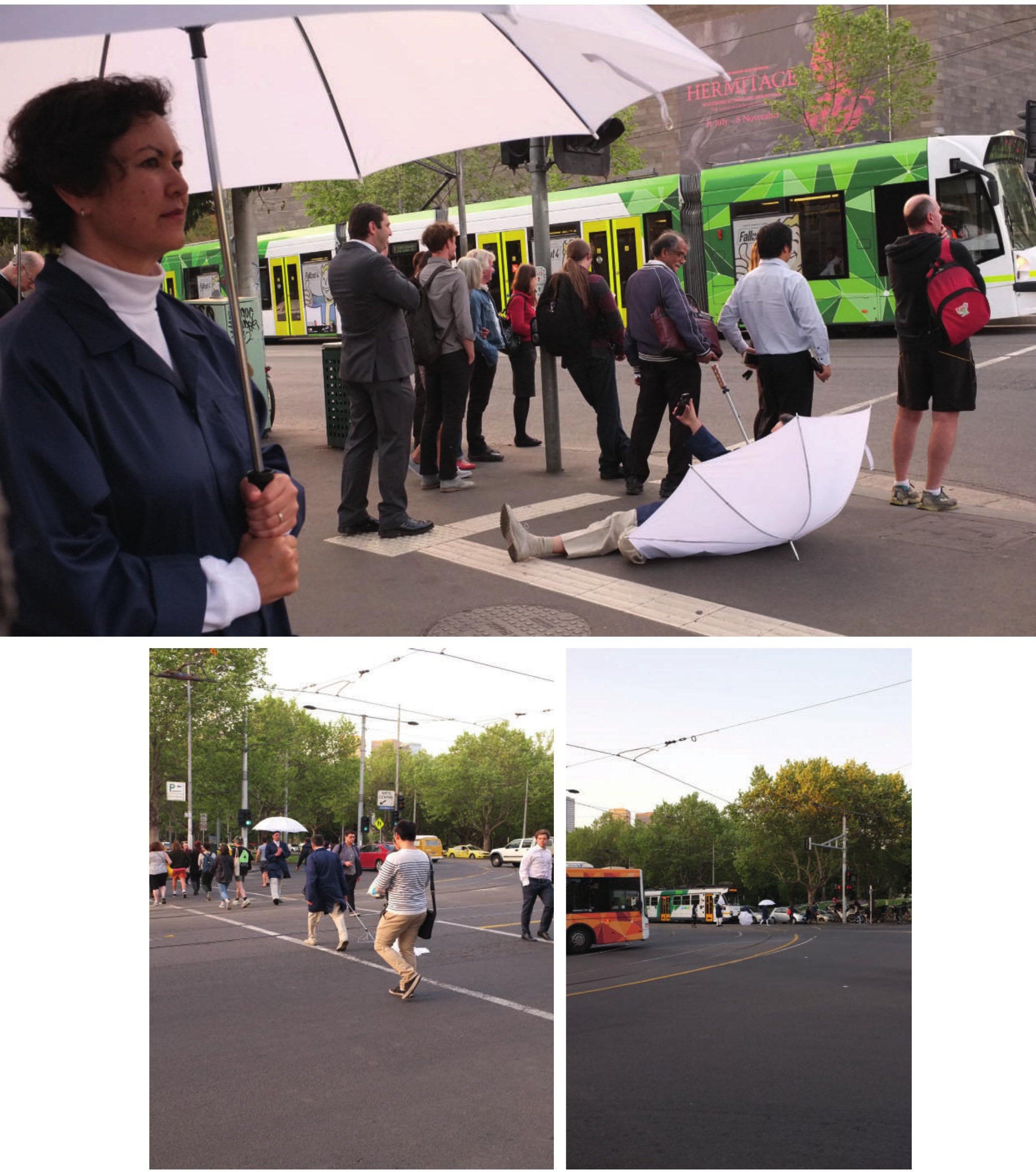

I6 I | The Journal of Public Space, 3 (2), 2018 | ISSN 2206-9658 


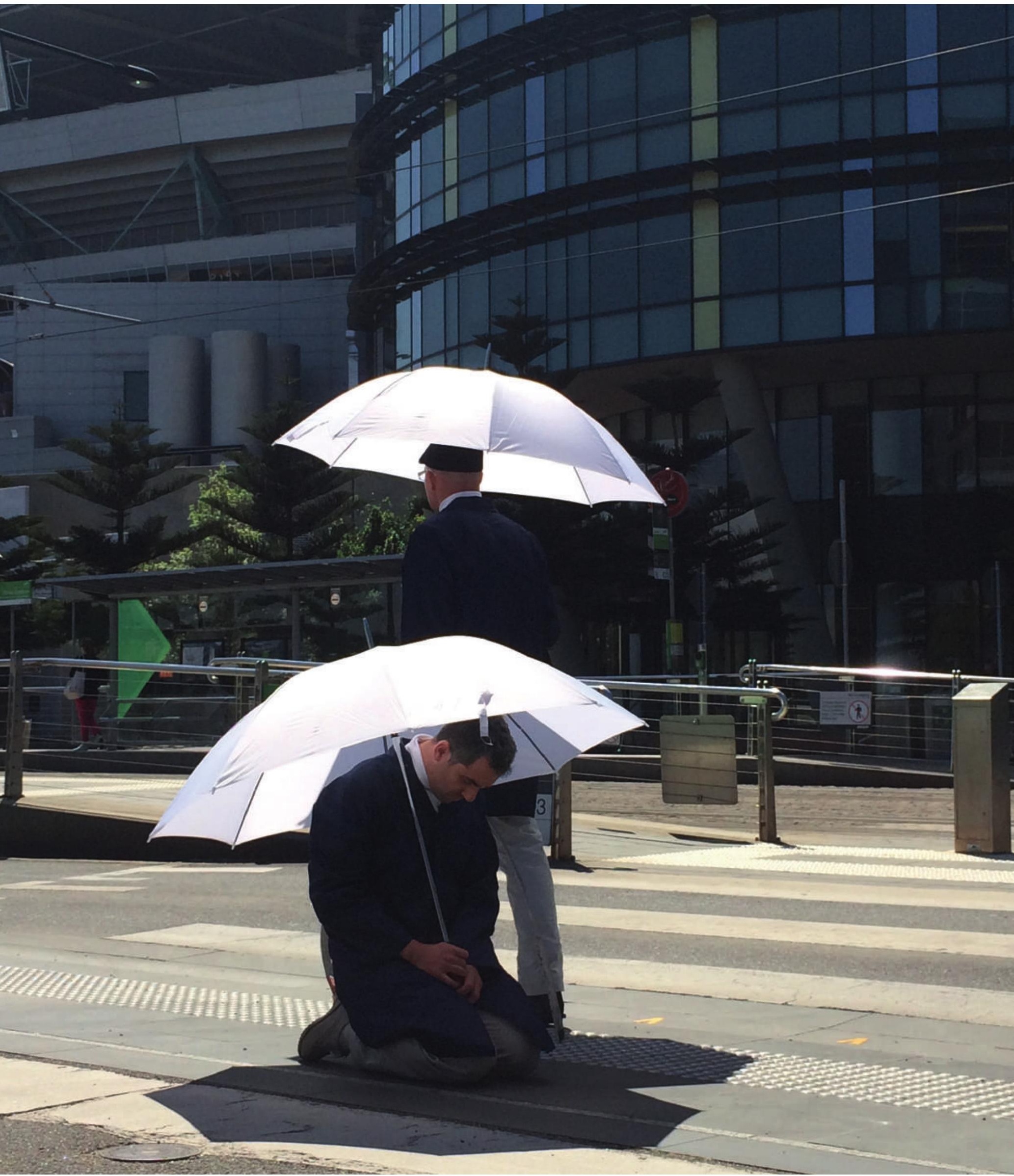

162 The Journal of Public Space, 3 (2), 2018 | ISSN 2206-9658

City Space Architecture / UN-Habitat 


\section{7'02.5'S I 44³8'02.0'E 2017}

\section{7}

The public work $37^{\circ} 57^{\prime} 02.5^{\prime \prime} S 144^{\circ} 38^{\prime} 02.0^{\prime \prime} \mathrm{E} 2017$ was located in the vast horizon of the Western Treatment Plant (WTP), where people have for generations shifted between the present and the future.A durational ensemble performance for the future was proposed as an act of recuperation. In the tradition of Edward Said and Daniel Barenboim's orchestra West-Eastern Divan (1999) the work is intended to trigger dialogue, between artists, audience and site.

$37^{\circ} 57^{\prime} 02.5^{\prime \prime}$ S $144^{\circ} 38^{\prime} 02.0^{\prime \prime} E$ was part of Treatment: Flightlines curated by Cameron Bishop and David Cross as an investigative creative project to creatively explore the Western Treatment Plant (WTP) in Melbourne's western districts, thirty-nine kilometers from Melbourne's Central Business District. Utilising the WTP as a test site of practice began as a journey to explore a rapidly transitioning landscape on the edge of Melbourne's urban sprawl as post-industrial sites are being remunerated and transformed into the contemporary urban Australian dream, a house on a quarter acre block. Werribee is renown historically and in the present as a test site in many ways.

Within the Western treatment plant lies the small abandoned township of Cocoroc. The township grew across time - houses, a community swimming pool, a town hall and football ground, tennis courts, schools and a post office. By the 1970s Cocoroc was home to a population of 500. In the 70s it was too expensive for the Melbourne and Metropolitan Board of works to maintain and residents were effectively relocated into the suburb of Werribee. What remains of the township now, and is imminently about to change is the Water Tower, the swimming pools, a football oval and change rooms and a community hall.

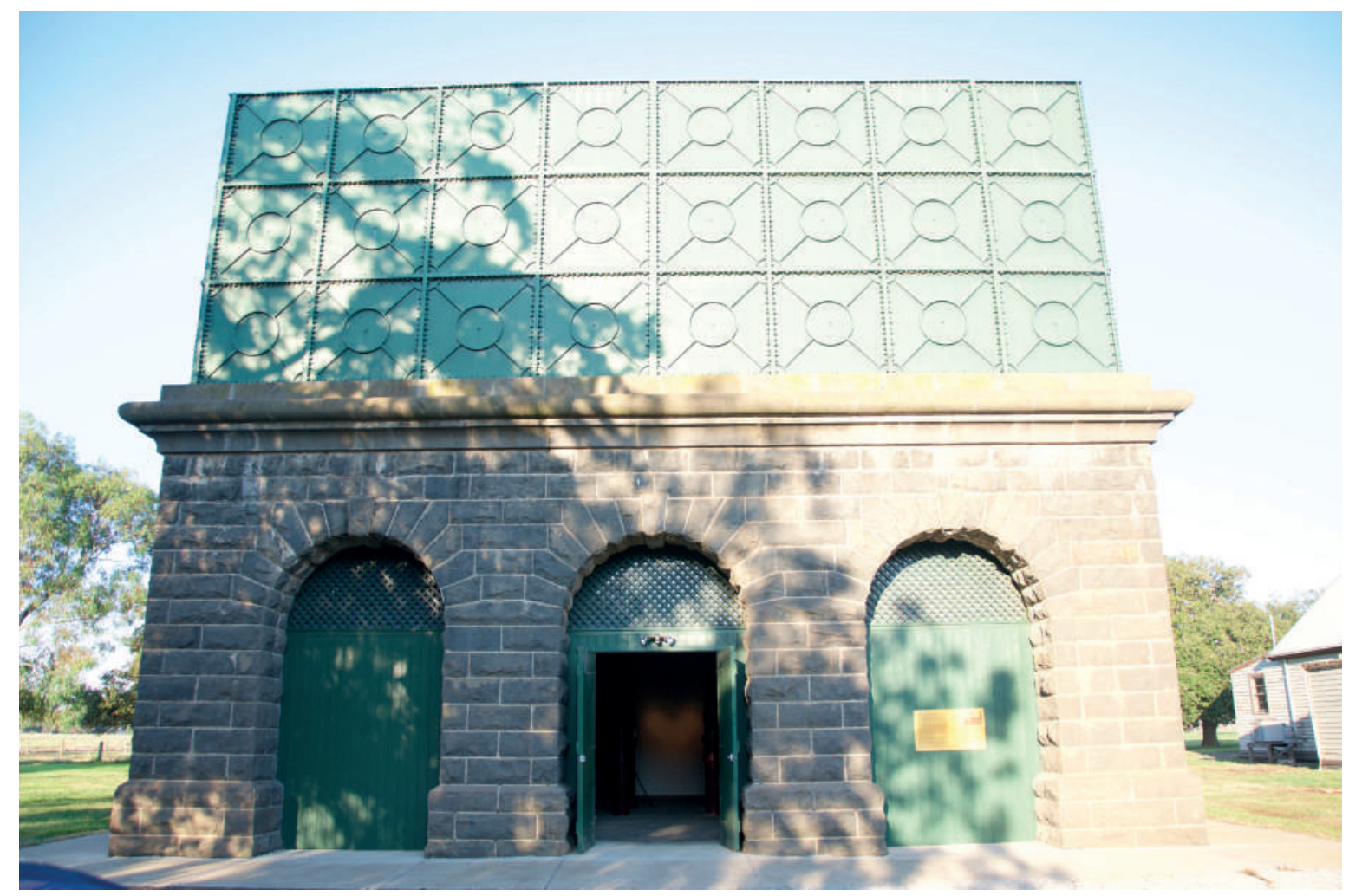

I63 | The Journal of Public Space, 3 (2), 2018 | ISSN 2206-9658 City Space Architecture / UN-Habitat 
A call out via social media invited respondents to submit a song that reminded them of the future, or that they would take into the future. Eighty nine songs later, with one original composition from one of the staff of the WTP, I extended an invitation to four electric guitarists; Billy Miller, Penny Ikinger, Sorcha Wilcox and Benjamin Cittadini to respond to the set list. Each guitarist chose four songs and through the seven hour performances they became abstracted, they became something else - a collaborative statement about the present, the time spent in the water tower, the resonance of the past and present reaching out across the landscape enveloping all that lay in its wake.

The work claimed the space in concert with the occupants of the site for those two seven hour performances.

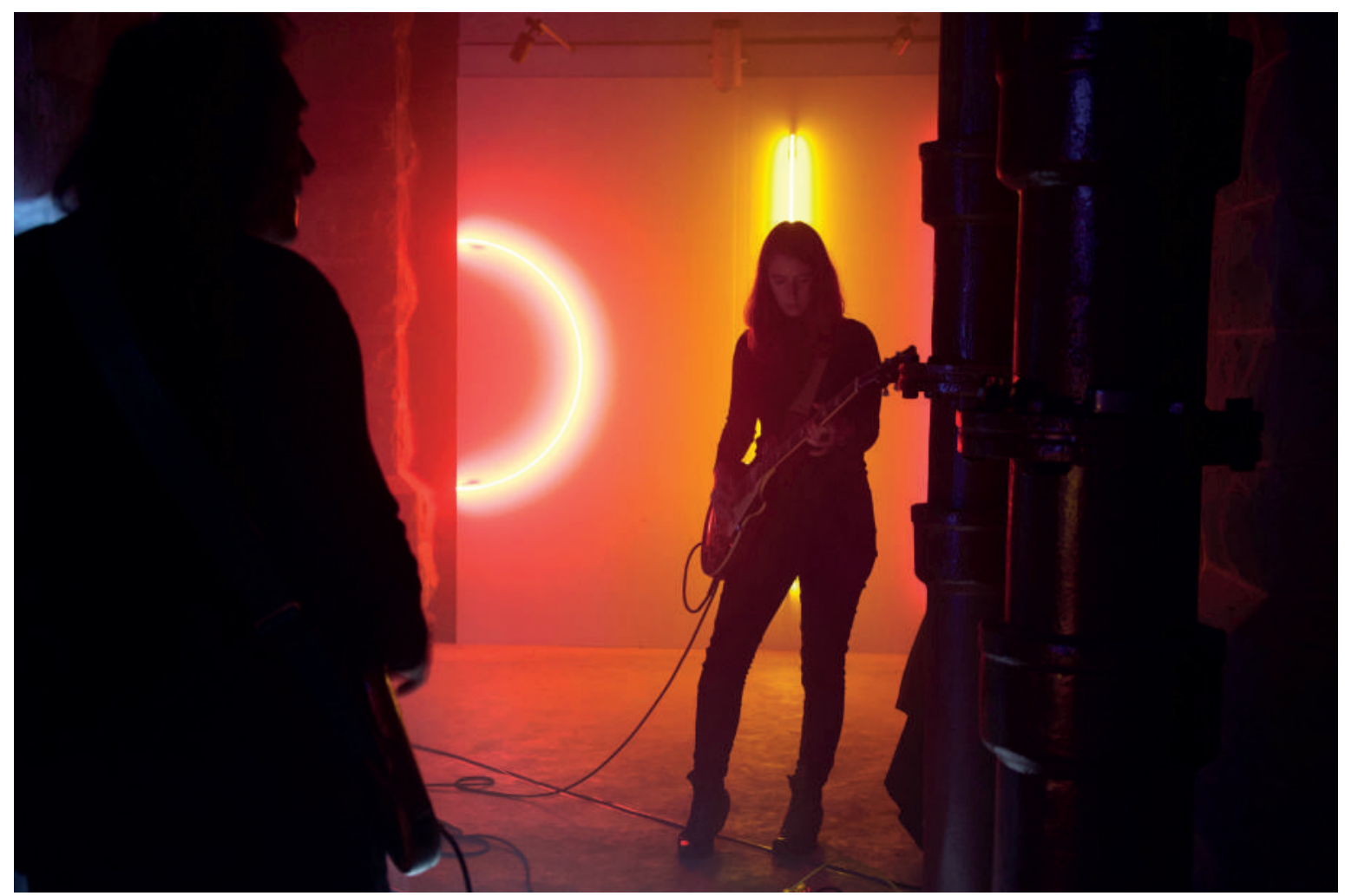



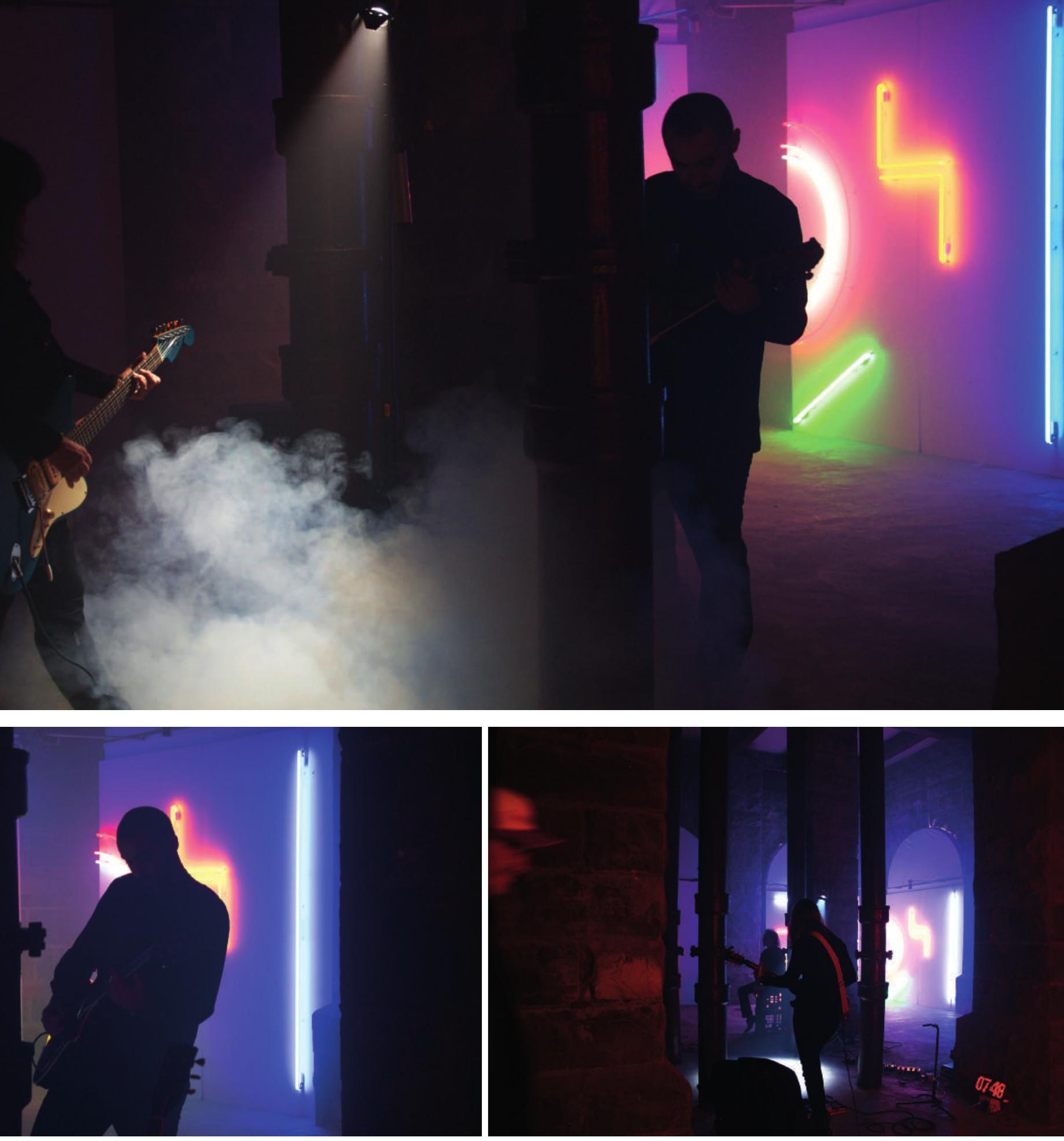

I65 | The Journal of Public Space, 3 (2), 2018 | ISSN 2206-9658 

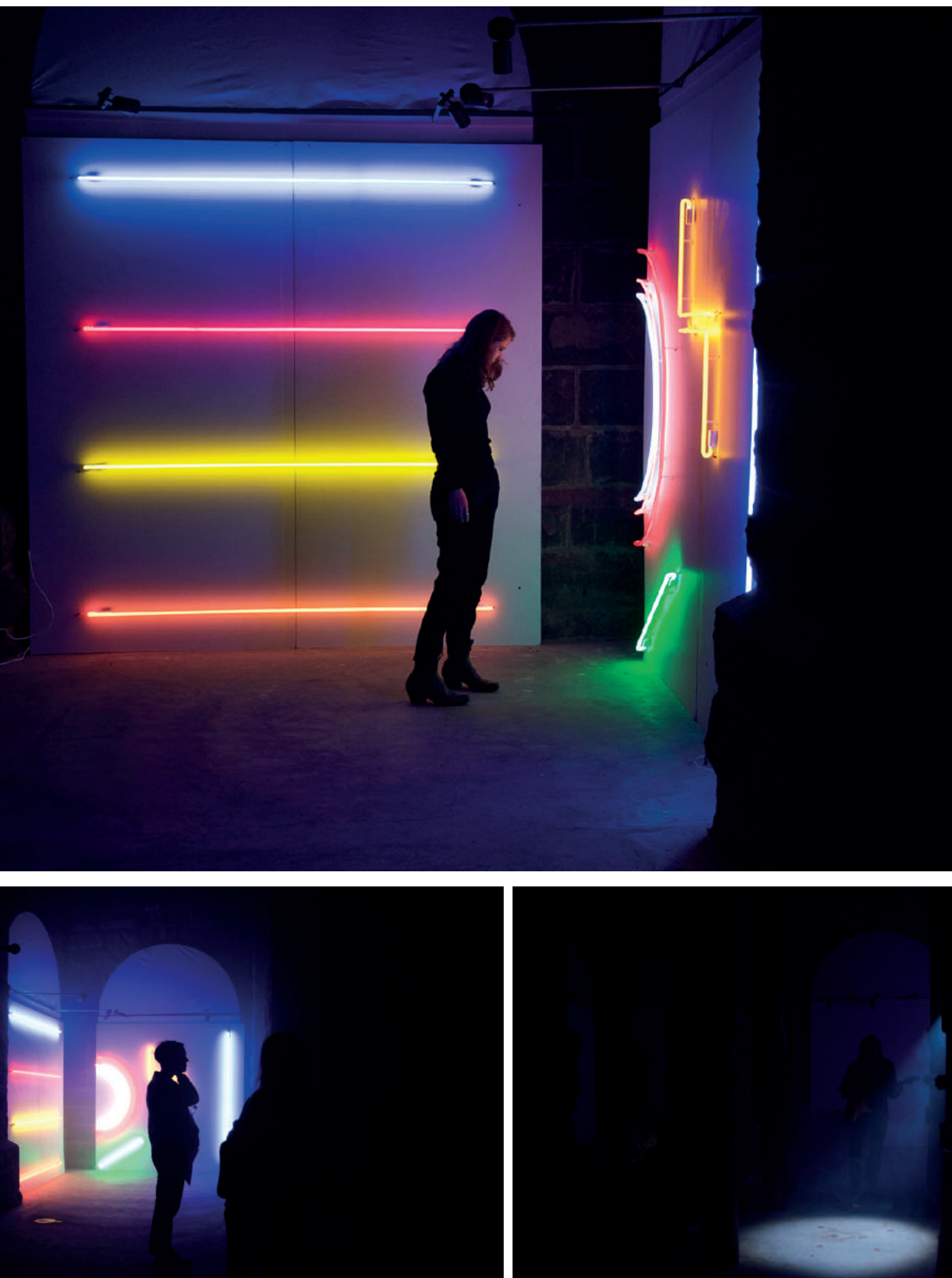

I66 | The Journal of Public Space, 3 (2), 2018 | ISSN 2206-9658

City Space Architecture / UN-Habitat 